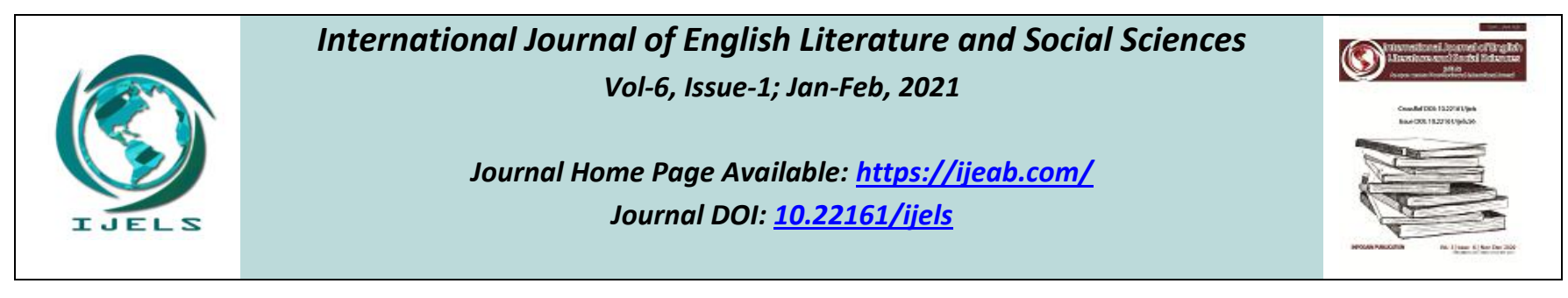

\title{
The images of Mahatma Gandhi in Anand's Novels
}

\author{
SK Abdul Salam
}

Research Scholar, North Orrisa University, Baripada, India

Received: 29 Oct 2020; Received in revised form: 02 Jan 2021; Accepted: 15 Jan 2021; Available online: 20 Jan 2021

(C)2021 The Author(s). Published by Infogain Publication. This is an open access article under the CC BY license (https://creativecommons.org/licenses/by/4.0/).

\begin{abstract}
The period 1920-1947 in the history of Indian's struggle for independence has been designated as "The Era of the Gandhian Revolution' in Indian literature. To the masses of people, Gandhi appeared as 'a tradition an oracle". He has to them a messiah, an incarnation of Rama of the Ramayana and Krishna of the Mahabharata who descended upon earth to kill the demon who held Indian in bondage for two hundred years and to free Indian from the yokes of foreign rule. He has known as the Mahatma ["great-souled"].It was his charisma and image that electrified the imagination of many Indo-English novelist who strove to "express, to reflect or to probe his ideal and ideas either directly or metaphorically, in their work.
\end{abstract}

Gandhiji himself was not a literature in the truest sense of the term but he frequently wrote in Indian Opinion, Young India and Harijan to champion the cause of India's freedom, to spread message of nonviolence and love of the downtrodden and the untouchables. His style was as simple as anything. It was free from rhetorical flourishes. He said, "I want art and literature that can speak to millions...For me all art must be based on truth. I reject beautiful things, if instead of expressing the truth, they express untruth."

Inspired by Gnddhi's simple style and approach to literature, they turned to the grim reality of contemporary socio-political scene averting their attention from writing historical romances, adventure stories or mystery novels. They were interested in the depiction of the life of the common man, the poor and the marginalized.

Keywords_ Gandhiji, India, Image, Freedom, Literature, Mahatma.

\section{INTRODUCTION}

The nineteen thirties, the seed time of modern independent India. It can be said to be a packed decade, packed with the Gandhian salt satyagraha movements of 1930, the 1932, the Three Round Table Conferences, the passing of the Government of India Act of 1935, the Gandhian movements for Harijan uplift and Basic Education etc. This struggle for freedom in India was so powerful that it became an all-pervasive emotional experience for all Indians. Most of the Indian writers could not escape the influence of these movements, especially the influence of Gandhiji on the minds of the people of that age. To take the words of Nahruji from his Discovery of India, " Gandhi was like a powerful current of fresh air that made us stretch ourselves and take deep breaths."
Living in the same age, Mulk Raj Anand too, like many of his contemporaries, could not but respond to the impact of events in India. Like most of the Indo-Anglian fiction of the thirties, Anand's novels are immensely influenced by the ideals of Mahatma Gandhi, who fought for the cause of the down-trodden, the marginalized and the defenseless. He admits it freely and states that his life got a ' $U$ ' turn when he came in contact with the ideals of Mahatma Gandhi.

Anand was so much influenced by Gandhiji that he stayed in Sabarmati Ashram with him for three months. During the same period he revised the manuscript of his famous novel Untouchable and Anand went through various sweet and sour experiences there. Thus 
Untouchable can be said to be written under the direct impact of that so-called 'old man' by Anand.

Gandhi makes a brief appearance in Untouchable towards the end. Lost in an agonizing reverie, Bakha, the hero of the novel, passes over a railway bridge. There he sees a great crowd in Golbag. Another big crowd is on the platform. As soon as a train arrives, the crowd rends the sky shouting, Mahatma Gandhi ki jai. The word 'Mahatma' was like a magical magnet, to which he, like all other people about him, rushed blindly. Gandhi was to them a saintly person like Guru Nanak, or "avatar of the gods Vishnu and Krishna. The Mahatma in his speech spoke of the British policy of creating separate electorates for the people of the depressed classes. He also spoke of the millions of human beings who were trampled underfoot for centuries without feeling the slightest remorse for own inequity. Gandhi also made a scathing criticism of the evils of untouchability which, he asserted firmly, was not sanctioned by religion. Bakha felt thrilled when he heard Gandhi saying : 'but if I have to be reborn, I should which to be reborn as an Untouchable, so that I may share their sorrows, suffering and the affronts leveled at them.... Therefore, I prayed that, if I should be born again, I should be so, not as a Brahmin, Kshatriya, Vaishya, Shudra, but as an outcast, as an untouchable. The meeting over, the people began to disperse discussing what Gandhi said. But a westernized Mohammedan went on abusing Gandhi. "Gandhi is a humbug. He is a fool. He is a hypocrite. In one breath he says he wants to abolish untouchability, in the other he asserts that he is an orthodox Hindu. He is running counter to the spirit of the age, which is democracy. He is in fourth century B.C. with his Swadeshi and his spinning-wheel. "Bakha heard the young poet say gently: 'He is by far the greatest liberating force of our age... He has his limits but he is fundamentally sound...' The image of Gandhi is projected in Untouchable through Dooli Singh, the village headman who upholds the cause of the untouchables against the cruelty and apathy of the caste-Hindus like Thakur Sing.

In Anand's another novel The Sword and the Sickle, the novelist shows his keen interest in Gandhi's ideas and ideologies. A Punjabi youth named Lal Sing is the protagonist in the novel. He returns to India after being released from a prison camp in Germany. He is an avowed communist and celebrates the anniversary of the Russian Revolution. Lal Sing organizes a peasant movement in Punjab but the movements suffers a major setback. He meets the Mahatma in the hope that Gandhi will help him alleviate the sufferings of the peasants. But Lal Sing is bewildered to hear Gandhi talk about the spiritual significance of tolerance, self-sacrifice and non-violence. $\mathrm{He}$ is also bewildered to see Gandhi's obsessive concern with the protection of cow and the age-old Hinduism. Lalu earnestly prays to Gandhi to go to Rajgarh, Gandhi future refuses to comply. Lalu and the party to which he belongs lose faith in Gandhi and becomes critical of Gandhi's ideas and ideals. But it is only at the end of The Sword and the Sickle Lalu finally comes to realize the truth of Gandhi's frim faith in the futility of violence.

In The Big Heart Mulk Raj Anand is critical of Gandhi's attitude to machines and industrialism. Mahasha Hans Raj represents the Gandhian view in the novel. He and his supporters Satyapal in particular and professor Majid uphold the gospel of Gandhi's Swadeshi and persuades the jobless thathiars [coppersmilhs] to boycott machines. The thatthiars are led to believe that the machines are not only the cause of unemployment but they also symbolize the imposition of British civilization in India. Anant is the novel's protagonist who sincerely wants to usher in the Age of Machine and who also wants to introduce trade unionism to ameliorate the condition of the working class. One jobless worker gatecrashes the factor and starts smashing machines. Anand who comes forward to protect machines is killed.

\section{CONCLUSION}

The novel, we have examined so far, project Gandhi as an apostle of sainthood, holiness and moral uprightness. $\mathrm{He}$ is portrayed as the architect of modern India. But in some novels Gandhi appears larger than life, and is much romanticized, mythologized and fictionalized.

\section{REFERENCES}

[1] Anand, Mulk Raj, Untouchable, New Delhi : Penguin Books, 2001.

[2] Sing, Khushwant, Train to Pakistan, Penguin Books London 1956.

[3] Walsh, William, R.K.Narayan : A Critical Appreciation, Heinemann, London, 1982.

[4] Iyenger, K.R. Srinivasa, Indian Writing in English.

[5] Naik, M.K., A History of Indian English Literature.

[6] Hossain, Dr. Akram, A Miscellany of Literary and Theoretical Essays. 